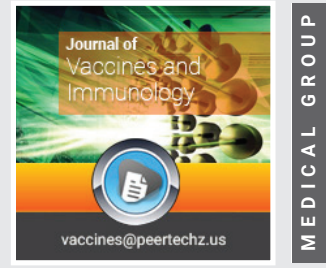

\section{Japanese Encephalitis (JE): A curse for people living in Uttar Pradesh, India}

\author{
Jay Prakash Patel ${ }^{1 *}$, Kusum Verma ${ }^{2}$ and Vijeta Singh ${ }^{3}$ \\ 'Department of Physics, Govt. P.G. College, Harakh, Barabanki-225121, Uttar Pradesh, India \\ ${ }^{2}$ Department of Microbiology, KNIPSS, Sultanpur-228118, Uttar Pradesh, India \\ ${ }^{3}$ ChemGeneics Research Foundation, Noida, 201301, Uttar Pradesh, India
}

Received: 08 September, 2021

Accepted: 24 September, 2021

Published: 04 October, 2021

*Corresponding author: Jay Prakash Patel,

Department of Physics, Govt. P.G.

College, Harakh, Barabanki-225121, Uttar Pradesh, India, Tel: +91-9506883488;

E-mail:patelitbhu@gmail.com

Keywords: Japanese Encephalitis Virus (JEV), Acute Encephalitis Syndrome (AES), Uttar Pradesh, India

Copyright: (C) 2021 Jay Prakash P, et al. This is an open-access article distributed under the terms of the Creative Commons Attribution License, which permits unrestricted use, distribution, and reproduction in any medium, provided the original author and source are credited.

https://www.peertechzpublications.com

\title{
Abstract
}

Japanese Encephalitis (JE) follows due to viral infection that directly affects brain leading to coma and finally death. JE which finally leads to Acute Encephalitis Syndrome (AES) have been creating devastation in eastern Uttar Pradesh for decades. The Gorakhpur in Uttar Pradesh is the epicenter of encephalitis induced deaths and the disease mostly affect its rural areas. However, Maharajgang, Sant Kabir Nagar, Basti, Kushinagar, Siddharth Nagar, Deoria and Mau are the most affected districts in the state. Independent figures put the toll around 50,000 as many kids die without reaching hospital. Every year, in rainy season the condition is worst for children in Uttar Pradesh. The Japanese Encephalitis Virus (JEV) is generally spread by mosquitoes, specifically those of the genus Culex. Pigs and wild birds serve as reservoir for the JEV. Encephalitis can be air or water borne, the result of a mosquito bite or spread by ticks. The initial symptoms are fever, cold or headache. However, it becomes life threatening only when it crosses the blood and brain barrier. There is no full cure of the disease; however, it can only be treated by vaccination to some extent. Prevention includes control of the vector mosquitoes of JEV by fogging with ultra-low levels of insecticides and by raising the immunity in children by vaccination. There are three types of vaccines has been used in large scale. In India, the JE vaccination was launched during 2006. Recently Shri Yogi Adityanath (Chief Minister, Uttar Pradesh) government has launched a massive encephalitis vaccination program during 2017-18 which is a positive hopeful step towards saving the lives of several innocent people of our country.

\section{Introduction about JE and AES in Uttar Pra- desh}

JEV infection occurs in the temperate and tropical regions all over the Asia. The countries which are severely affected by this virus in last few years are China, Korea, Japan and India as well as some other countries of Asia [1]. However, most of them such as China, Korea, Japan, Taiwan and some others have controlled the spread of disease by vaccination [2]. In India, JE infection becomes a major problem of pediatric health departments and the epidemics are reported time to time from many parts of the country. For the first time in $1924 \mathrm{JE}$ was identified in Japan. In India the first case of JE based on serological surveys was reported from Tamil Nadu in 1955. After that a total of approximately 65 cases were reported in between 1955-1966 from southern India. A major outbreak resulting in a $42.6 \%$ fatality rate was reported in Bankura district of West Bengal in 1973 [3]. In Uttar Pradesh, the first major JE epidemic occurred in Gorakhpur in 1978 with 1002 cases and 297 deaths were reported [4]. However, recently on August 9-10, 2017, the deaths of over 30 kids in 48 hours reportedly due to negligence in encephalitis treatment ward and lack of oxygen supply at Baba Raghav Das (BRD) medical college has accelerated political war between government and opposition parties [5]. However, the death of JE affected ones is not new. The hospital had been an eyewitness to such tragedies in the past too. Gorakhpur has been in the grip of JE and AES for four decades [6]. Encephalitis occurs due to viral infection that directly affects brain leading to coma and finally death [7]. Gorakhpur is the epicenter of encephalitis induced deaths and the disease mostly affect its rural areas [8]. Gorakhpur is recognized for the cultivation of paddy. This has directed for the massive augmentation of the watering system which bolsters the breeding of the mosquitoes. The region mostly undergoes 
prolonged subtropical climate with 4 seasons namely winter from the month of December to February, pre-monsoon from March to May, monsoon from June to September and post monsoon season from October to November. Throughout the entire year the average highest temperature ranges from 22 $38^{\circ} \mathrm{C}$ and the average lowest temperature ranges from $9-26^{\circ} \mathrm{C}$. Besides the suitable agronomic and geographical conditions, the epidemic hazard was highly related with the suitable habitat of the birds and the density of pigs along with the joint landscapes among split rainfed agriculture and each freshwater and river wetlands [9].

Population in Uttar Pradesh depends on agriculture which aids the state economy to much extent. According to location and season the condition of weather changes significantly. In east Uttar Pradesh five district (Siddharth Nagar, Sant Kabir Nagar, Kushinagar and Gorakhpur) are very prone to JE due to every year flood conditions there. In these areas flooding affect crops, community life and economy. Here people also depend on domestic animals like goats, cows, pigs, buffaloes, horses, and dogs. JEV amplifies very rapidly in pigs but most of the population is unaware of this JEV reservoir [9]. In recent years independent figures put the toll around 50,000 as many kids die without reaching hospital. If we take an average death into account in recent years, it was 19 children per day in 2014, 22 in 2015, 19 in 2016 and in 2017 it is 23. Every year, in rainy season the condition is worst for children in Gorakhpur [10]. The Japanese Encephalitis Virus (JEV) is generally spread by mosquitoes, specifically those of the genus Culex. Pigs and wild birds serve as reservoir for the JEV. Encephalitis can be air or water borne, the result of a mosquito bite or spread by ticks. The initial symptoms are fever, cold or headache. However, it becomes life threatening only when it crosses the blood and brain barrier [10]. This report presents the status and trends of JE and AES cases in Uttar Pradesh through the data obtained from health authorities and draw out seasonal variations in the occurrence of cases and mortality along with other details associated with the disease.

\section{Recent data on yearly destruction due to JE and AES in Uttar Pradesh}

Uttar Pradesh has been reporting outbreaks of encephalitis since 1978. The major outbreaks occurred in 1978, 1988 and again in 2005 where case numbers and corresponding fatalities were significantly higher. The disease mostly affects $1-5$ year old children mainly at the time of monsoon [11]. Since 19782017 due to JE there was around 50,000 deaths has been recorded in Uttar Pradesh. The infectious disease persists to stick as a serious public health issue in India [13]. According to recent report from 2005-2018, the total cases of AES reported were 47,509 in Uttar Pradesh among them 8373 were died [14]. The data according to Directorate of NVBDCP (National Vector Borne Disease Control Programme), on JE and AES from Uttar Pradesh since 2010 [15] are given in Figure 1.

Since 2010-2020, the maximum confirmed cases and deaths due to AES and JE in Uttar Pradesh were reported in 2017 i.e. AES cases 4724 with 654 deaths, however, 693 cases with 93 deaths due to JE [14]. A continuous decline in the confirmed cases and deaths of JE and AES was observed after 2017 onwards. In 2020 only $100 \mathrm{JE}$ confirmed cases with 9 deaths were reported. Similarly for AES the confirmed cases were 1641 with 83 deaths in 2020 , which, revealed that the condition is much better than the last few years in Uttar Pradesh.

\section{About JEV and its transmission}

JEV belongs to the family Flaviviridae. The family name is after yellow fever virus, which is a typical virus of this family. In latin, flavus means yellow and the name yellow fever is because of susceptibility to cause jaundice in victims by the virus [16]. In this family, among the four genera (Pegivirus, Pestiviruses, Hepaciviruses and Flaviviruses) there are more than 100 species are currently known. The family Flaviviridae associated diseases includes: hemorrhagic syndromes, hepatitis (hepaciviruses), fatal mucosal disease (pestiviruses), encephalitis, hemorrhagic fever and the birth defect microcephaly (flaviviruses). The family is a serocomplex
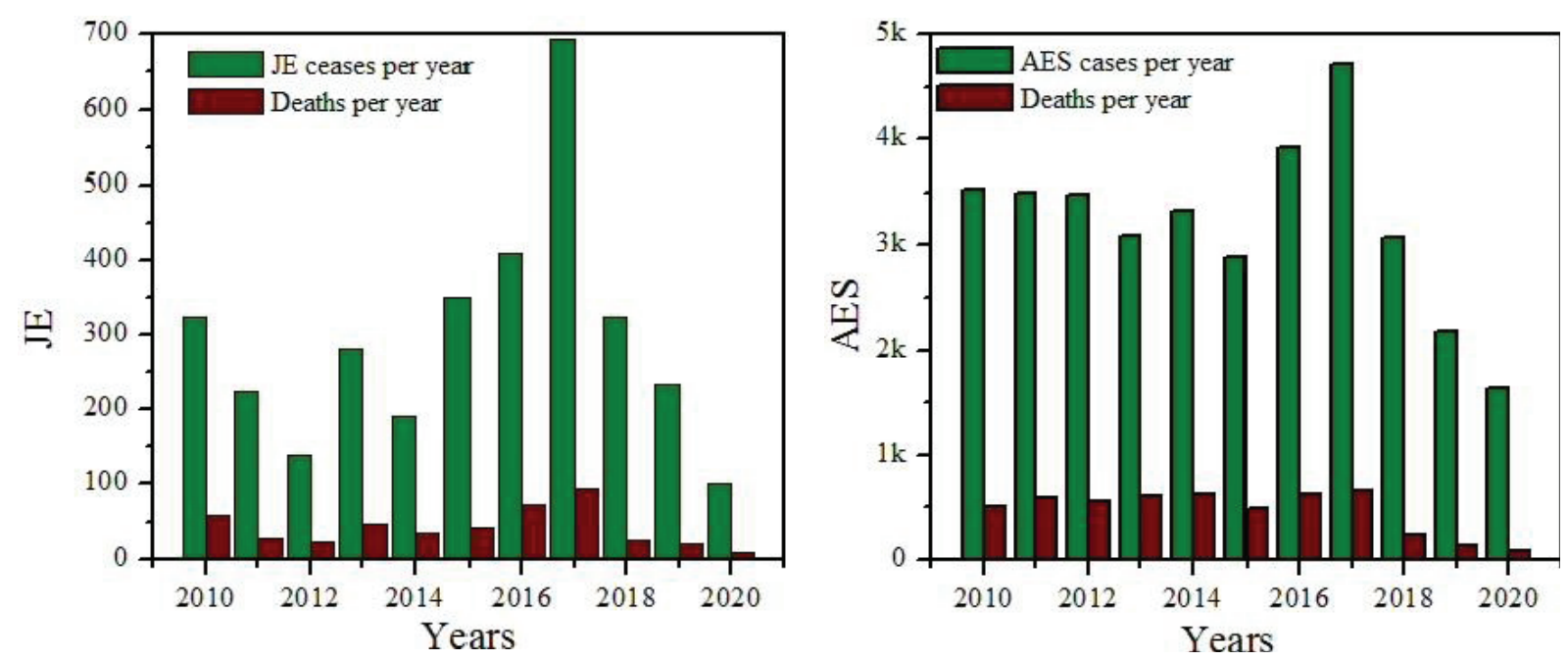

Figure 1: JE and AES confirmed cases and deaths in Uttar Pradesh since 2010 onwards. (Data source is NVBDCP \{National Vector Borne Disease Control Programme\} website).

Citation: Jay Prakash P, Kusum V, Vijeta S (2021) Japanese Encephalitis (JE): A curse for people living in Uttar Pradesh, India. J Vaccines Immunol 7(1): 036-040. DOI: https://dx.doi.org/10.17352/jvi.000045 
of nine antigenically and genetically related viruses, few of them are predominantly severe in horses while four are known to infect human beings [17]. The single stranded positive sense RNA genome is monopartite, linear and 9.6 to 12.3 kilobase in length which is packaged in the capsid (a protein part). A number of nonstructural proteins (NS1, NS2a, NS3, N4a, NS4b and NS5) are also encoded by the genome. The proteins; $\mathrm{NS}_{1}$ and NS2a are generated as secretary forms. $\mathrm{NS}_{3}$ and $\mathrm{NS}_{5}$ are putative helicase and viral polymerase respectively. It is evident from published reports that JE invades the host cells by infecting lumen of the endoplasmic reticulum [18] Figure 2.

The transmission of JEV occurs mainly in rural agricultural areas often related with production of rice and flooding irrigation. At some places of Asia, these conditions may occur near urban cores. Area having temperate conditions in Asia, the transmission of JE virus is seasonal. The disease in human usually peaks in the rainfall and summer. JE is a vector borne disease and a zoonotic infection. The disease is spread to man by the bite of mosquitoes of the genera Culex [19]. Mainly the most vital vectors of JE virus found in Gorakhpur region of the Uttar Pradesh is the female mosquito Culex tritaeniorhynchus. Culex vishnui and Culex pseudovishnui are the others from this group [20]. JE virus is primarily zoonotic in its natural cycle and man is an accidental host. JE virus is neurotorpic and arbovirus and primarily affects central nervous system. It will take 3 months for JE cases to appear after the start of monsoon.
Vector mosquitoes multiply profusely during monsoon which leads to increase in JEV and mosquito-human contact. The JEV transmission ultimately increases the JE cases. The JE is a brain infection caused by JEV that is upheld in a cycle between mosquitoes and vertebrate hosts (primarily pigs and birds). Water birds of Ardeidae family (mainly cattle egrets and pond herons) are the natural hosts of JE virus. In this natural cycle pigs play a key role and serve as an amplifier host. They permit manifold virus growth without suffering from disease and uphold prolonged viraemia [20]. Due to this, mosquitoes get chance to pick up infection from pigs easily. Human beings are the dead-end or incidental hosts as they usually do not develop required concentrations of the virus in their blood to infect the mosquitoes [21].

\section{Clinical manifestations}

Clinically, cases of JE show symptoms and signs similar to viral origin encephalitis. Initially it was believed that all cases were caused by the JEV, a mosquito-borne disease but subsequent testing has shown that only about $13 \%$ of cases test positive for JE. As JE includes very nonspecific manifestations and in patients' frequent seizures misleads the symptoms of many other causes that may be bacterial, viral, fungal and protozoan. As a result for the easiness of diagnosis and facilitation of observation the NVBDCP in 2006 modified the JE case definition i.e. "AES case is identified as if a person of
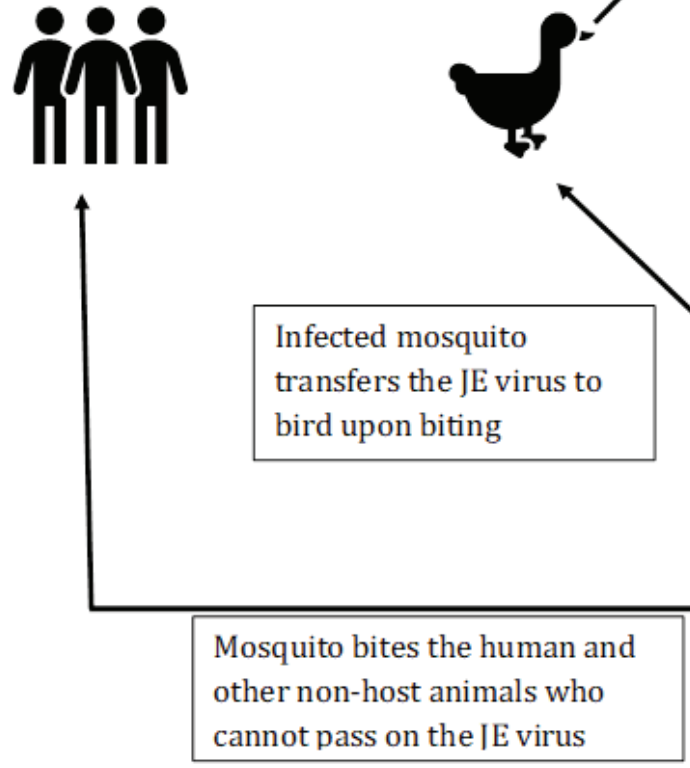
any age and at any time is facing a change in mental status with the acute onset of fever with symptoms of confusion, disorientation leading to coma or talking inability". Thus, JE has been the leading cause of AES in Asia [15]. JE diagnosis therefore aims to find a patient with AES and then confirmation of JEV. The incubation period of JEV ranges between 2-15 days however, the most of the infections have no symptoms. The key manifestations are; headache, laziness and fever. The signs which developed during the AES include cachexia, neck

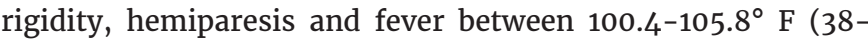
$41^{\circ} \mathrm{C}$ ). At later stages it usually leads to a condition of mental retardation. There is variation in mortality rate of this disease but it greatly affects children. Impairment of central nervous system causes long-lasting neurological defects which involve emotional labiality, deafness, and hemiparesis [22].

\section{Diagnosis of JE disease}

The diagnosis is based on commercially accessible confirmatory tests detecting JEV specific antigens and antibodies. For antibody, Compliment Fixation Test (CF), Hemagglutination Inhibition Test (HI) and Enzyme Linked Immuno-Sorbent Assay (ELISA) for IgG (paired) and IgM (MAC) antibodies. Similarly, for antigens a rapid sensitive and specific reverse passive hemagglutination test (RPHA), Immunofluorescence assay (IFA) and immunoperoxidase test. However, due to various limitations associated with most of the above mentioned tests the IgM ELISA test is the most popular. The sample is IgM antibodies in cerebrospinal fluids/serum from patients within 3-5 days after infection [14]. However, after 8 days there is no detectable IgM can be found in serum [23]. Confirmatory testing in the United States is only offered at Centers for Disease Control and Prevention (CDC) and at some specific reference laboratories [24]. An indirect fluorescent antibody staining is used for showing viral antigens in tissues.

\section{Treatment}

There is no specific anti-viral medicine available against JE virus and so there is no full cure of the disease. However, it can only be treated by vaccination to some extent. Prevention includes control of the vector mosquitoes of JEV by fogging with ultra-low levels of insecticides and by raising the immunity in children by vaccination. There are three types of vaccines has been used in large scale; Cell culture derived inactivated vaccines, Mouse brains derived vaccines and Cell culture live attenuated vaccines. Currently three vaccines are available; SA-I4-I4-2, ICS1 (Marketed as JESPECT in New Zealand and Australia and as IMOJEV elsewhere). Now a days all vaccines are based on the genotype-III virus [25]. Vaccination for JE was started in 2006 in India for 1 to 15 years old children. After that single dose of JE vaccine (SA-I4-I4-2) was used under universal immunization programme. Community awareness needs to be developed for individual safety against mosquito bites and for the early diagnosis of JE cases.

\section{Approaches and program undertaken by different orga- nizations to fight against JE}

At the world level, the execution of vaccination program for children as well as improved agricultural practices, pig vaccination and vector control has reduced the number of JE cases. During 2006 in India, the JE vaccination was launched. The most sensitive 11 districts including Karnataka, Assam, West Bengal and Uttar Pradesh have been covered. For the JE/ AES case management various Re-orientation training courses are ongoing and in schedule. Many awareness programs have been running in Tamil Nadu, Andhra Pradesh, West Bengal and Uttar Pradesh since 2008 [26]. Numerous vaccines are still in various phases of development. The BRD (Baba Raghav Das) medical College hospital is the only hospital in Gorakhpur, Uttar Pradesh in a 3000 sq. kms. stretch of the region with facilities to treat encephalitis diseases. Besides this Shahuji Maharaj Medical University, Lucknow and Sanjay Gandhi Post Graduate Institute of Medical Sciences, Lucknow have good facilities for diagnosis and treatment of JE cases. Recently Yogi Adityanath (Chief Minister, Uttar Pradesh) government has launched a massive encephalitis vaccination programme during 2017-18 which covered 8.8 million children [27]. It is a positive hopeful step towards saving the lives of several innocent people of the country.

\section{References}

1. Centers for disease control and prevention 2019.

2. Kraft SY (2018) What's to know about Japanese encephalitis? Medical News Today.

3. Dhillon GP, Raina VK (2008) Epidemiology of Japanese encephalitis in context with Indian scenario. J Indian Med Assoc 106: 660-663. Link: https://bit.ly/3AEtMR6

4. Tiwari S, Singh RK, Tiwari R, Dhole TN (2012) Japanese encephalitis: a review of the Indian perspective. Braz $\mathrm{J}$ Infect Dis 16: 564-573. Link: https://bit.ly/3ELfpNb

5. Gorakhpur hospital tragedy: 30 children die in 48 hours after oxygen supply disrupted; magisterial probe ordered. The Hindustan Times. Link: https://bit.ly/3CLSVKn

6. Dutta PK (2017) Gorakhpur has a history of children's death, 25,000 kids have lost lives to encephalitis. India Today. Link: https://bit.ly/3ACOvVi

7. Ambardekar N (2021) Understanding Encephalitis-The Basics. Link: https://wb.md/3o1PrPw

8. Sharma SM (2017) Gorakhpur's Japanese encephalitis malady; Ideas for India. Link: https://bit.ly/3zC5xlk

9. Singh H, Singh N, Mall RK (2020) Japanese Encephalitis and Associated Environmental Risk Facotrs in Eastern Uttar Pradesh: A time series analysis from 2001 to 2016. Acta Tropica 212: 10570. Link: https://bit.ly/2XK9qak

10. Bajpai N (2017) Gorakhpur tragedy: Is August the cruelest month for BRD Medical College? The New Indian Express. Link: https://bit.ly/3ARTqC9

11. Folly AJ, Dorey-Robinson D, Hernández-Triana LM, Ackroyd S, Vidana $B$, et al. (2021) Temperate conditions restrict Japanese encephalitis virus infection to the mid-gut and prevents systemic dissemination in Culex pipiens mosquitoes. Sci Rep 11: 6133. Link: https://go.nature.com/3IXDfwA

12. Singh AK, Kharya P, Agarwal V, Singh S, Singh NP, et al. (2020) Japanese encephalitis in Uttar Pradesh, India: A situational analysis. J Family Med Prim Care 9: 3716-3721. Link: https://bit.ly/3o2gfPK

13. Narain JP, Dhariwal AC, MacIntyre CR (2017) Acute encephalitis in India: An unfolding tragedy. Indian J Med Res 145: 584-587. Link: https://bit.ly/2XX7snF 
14. Kelly R (2019) Encephaliltis in Uttar Pradesh: Has Yogi Adityanath solved the problem? Health Express. Link: https://bit.ly/2XX7AUb

15. The Directorate of National Vector Borne Disease Control Programme (NVBDCP) Website: Link: https://nvbdcp.gov.in

16. Ghosh D, Basu A (2009) Japanese encephalitis-a pathological and clinical perspective. PLoS Negl Trop Dis 3: e437. Link: https://bit.ly/2Zx5tHf

17. Lobigs M, Diamond MS (2012) Feasibility of cross-protective vaccination against flaviviruses of the Japanese encephalitis serocomplex. Expert Rev Vaccines 11: 177-187. Link: https://bit.ly/3IWXhay

18. Jan LR, Yang CS, Trent DW, Falgout B, Lai CJ (1995) Processing of japanese encephalitis virus non-structural proteins: NS2B-NS3 complex and heterologous proteases. J Gen Virol 76: 573-580. Link: https://bit.ly/3CJ9RAY

19. Lord JS, Gurley ES, Pulliam JR (2015) Rethinking Japanese Encephalitis Virus Transmission: A Framework for Implicating Host and Vector Species. PLoS Negl Trop Dis 9: e0004074. Link: https://bit.ly/3hYiU9p

20. Pearce JC, Learoyd TP, Langendorf BJ, Logan JG (2018) Japanese encephalitis: the vectors, ecology and potential for expansion. J Travel Med 25: S16-S26. Link: https://bit.ly/3uahldu

21. Weaver SC, Barrett AD (2004) Transmission cycles, host range, evolution and emergence of arboviral disease. Nat Rev Microbiol 2: 789-801. Link: https://bit.ly/3ACWMIQ
22. Simon LV, Sandhu DS, Goyal A, Kruse B (2021) Japanese Encephalitis In: StatPearls [Internet]. Treasure Island (FL): StatPearls Link: https://bit.ly/3i4YmvP

23. Solomon T, Thao LT, Dung NM, Kneen R, Hung NT, et al. (1998) Rapid diagnosis of Japanese encephalitis by using an immunoglobulin $M$ dot enzyme immunoassay. J Clin Microbiol 36: 2030-2034. Link: https://bit.ly/3o13C7F

24. Centers for Disease Control and Prevention, National Center for Emerging and Zoonotic Infectious Diseases (NCEZID). Division of Vector-Borne Diseases (DVBD). Link: https://bit.ly/3hZ4yWc

25. Han N, Adams J, Chen P, Guo ZY, Zhong XF, et al. (2014) Comparison of genotypes I and III in Japanese encephalitis virus reveals distinct differences in their genetic and host diversity. J Virol 88: 11469-11479. Link: https://bit.ly/3o5col0

26. Case study: India's leadership in the fight against Japanese encephalitis by Center for Vaccine Innovation and Access. Link: https://bit.ly/3hZx4XB

27. Jadid A (2017) UP CM Yogi Adityanath launches campaign to eradicate Japanese Encephalitis. Hindustan Times. Link: https://bit.ly/3zHPWAp

\section{Discover a bigger Impact and Visibility of your article publication with} Peertechz Publications

\section{Highlights}

* Signatory publisher of ORCID

* Signatory Publisher of DORA (San Francisco Declaration on Research Assessment)

* Articles archived in worlds' renowned service providers such as Portico, CNKI, AGRIS, TDNet, Base (Bielefeld University Library), CrossRef, Scilit, J-Gate etc.

* Journals indexed in ICMJE, SHERPA/ROMEO, Google Scholar etc.

* OAI-PMH (Open Archives Initiative Protocol for Metadata Harvesting)

* Dedicated Editorial Board for every journal

* Accurate and rapid peer-review process

* Increased citations of published articles through promotions

- Reduced timeline for article publication

Submit your articles and experience a new surge in publication services (https://www.peertechz.com/submission).

Peertechz journals wishes everlasting success in your every endeavours. 